\title{
Epidural Capillary Hemangioma of the Thoracic Spine
}

\section{Hemangioma capilar extradural da coluna torácica}

\author{
Eberval Gadelha Figueiredo ${ }^{1}$ Anderson Rodrigo Souza ${ }^{1}$ Gabriel Reis Sakaya ${ }^{1}$ \\ Daniella Brito Rodrigues ${ }^{2}$ Raul Marino Jr. ${ }^{3}$ \\ ${ }^{1}$ Department of Neurological Surgery, Institute of Neurological \\ Diseases of São Paulo, São Paulo, SP, Brazil \\ 2 School of Medicine, Universidade do Estado do Pará, Belém, PA, Brazil \\ ${ }^{3}$ Department of Neurological Surgery, Institute of Neurological \\ Diseases of São Paulo, Beneficencia Portuguesa Hospital, São Paulo, \\ SP, Brazil \\ Arq Bras Neurocir 2015;34:313-316. \\ Address for correspondence Eberval G. Figueiredo, MD, PhD, \\ Maestro Cardim 808, São Paulo, SP, Brazil 01323-001 \\ (e-mail: ebgadelha@yahoo.com).
}

\begin{abstract}
Keywords

- hemangiomas

- spinal cord

- capillary hemangioma

- neurilemmoma

Background Hemangiomas are congenital vascular malformations pathologically considered as harmatomas and classified as capillary, cavernous, arteriovenous or venous, and usually located at soft tissue or bone, mainly in the spinal column. Pure epidural capillary hemangiomas are extremely rare lesions that should be included in the differential diagnosis of spinal epidural lesions; only three patients with epidural capillary hemangiomas have been reported to date.

Case Report We report a case of a 57-year-old man that complained of dorsal and back pain. The neurological examination revealed back tenderness and crural paraparesis. His reflexes were exaggerated and Babinski sign was present on both sides. A magnetic resonance imaging showed an epidural lesion at the level of T10-12 that demonstrated extension with intense postgadolinium enhancement. These lesions were different from more common lesions, mainly schwanommas, mainly due to the foraminal extension, which sets them apart from cavernous hemangiomas. The surgical ressection was performed. After laminectomy, a reddish epidural mass that extended into the right $\mathrm{T} 11-12$ foramina was revealed. The feeding vessels had to be identified and divided. In such cases, the surgeon must carefully dissect the lesion circumferentially away from the dura and employ judicious hemostasis. The patients histopathological examination revealed a vascular tumor composed of vessels of several calibers. The imagery obtained from the exams led to the diagnosis of a capillary hemangioma.

Conclusions Pure epidural capillary hemangiomas should be included in the differential diagnosis of spinal epidural lesions, mainly schwanommas, especially due to the foraminal extension, which may differentiates them from cavernous hemangiomas. Surgical excision is mandatory and intervertebral foraminal extension may preclude gross total resection.
\end{abstract}

received

August 9, 2014

accepted

August 7, 2015

published online

October 19, 2015
DOI http://dx.doi.org/

10.1055/s-0035-1564421. ISSN 0103-5355.
Copyright $(\underset{0}{ } 2015$ by Thieme Publicações License terms

Ltda, Rio de Janeiro, Brazil 


\section{Resumo \\ Introdução Os hemangiomas são malformações vasculares congênitas patologica- mente consideradas como hamartomas. Podem ser classificadas como capilar, caver- noso, arteriovenoso ou venoso, e são geralmente localizadas em tecidos moles ou ossos, principalmente na coluna vertebral. Hemangioma capilar epidural puro é uma lesão extremamente rara que deve ser incluída no diagnóstico diferencial das lesões espinais epidurais, foram relatados casos de apenas três pacientes com hemangiomas capilares epidurais. \\ Relato de Caso Relatamos o caso de um homem de 57 anos de idade com queixa de dorsalgia. Ao exame neurológico, paraparesia crural, com hiperreflexia e sinal de Babinski bilateral. A ressonância magnética mostrou uma lesão epidural no nível de T10-12 com intenso realce pós-gadolíneo. Hemangioma capilar deve ser diferenciado de lesões mais comuns, principalmente schwannomas, devido à extensão foraminal. A ressecção cirúrgica foi realizada. Um processo expansivo epidural avermelhado, se estendendo para o forâmen direito de T11-12, tornou-se evidente após a laminecto- mia. Os vasos que o irrigavam foram identificados e adequadamente separados. A lesão foi cuidadosamente dissecada circunferencialmente e uma hemostasia criteriosa foi realizada. O exame histopatológico revelou um tumor vascular composto por vasos de \\ Palavras-chave \\ - hemangiomas \\ - medula espinhal \\ - hemangioma capilar \\ - neurilemoma vários calibres. Exames de imagem corroboraram com a hipótese de um hemangioma capilar. \\ Conclusões Hemangiomas capilares epidurais puros devem ser incluídos no diag- nóstico diferencial das lesões da coluna vertebral epidural, principalmente schwanom- mas, especialmente devido à extensão foraminal. A excisão cirúrgica é obrigatória e a extensão para o forame intervertebral pode impossibilitar a ressecção total.}

\section{Introduction}

Capillary hemangioma, also known as "Infantile hemangioma," appears as a raised red lumpy lesion occurring anywhere on the body, although $83 \%$ are located in the head or neck area. ${ }^{1-6}$ Most of the epidural hemangiomas described in the literature were cavernous hemangiomas. ${ }^{1,2,7}$ Epidural capillary hemangiomas are exceedingly rare lesions. Thus far, only three cases have been reported. ${ }^{4,7}$ We describe an additional case of a purely epidural capillary hemangioma and discuss its clinical, radiological, therapeutic, and prognostic features.

\section{Case Report}

A 57-year-old man complained of dorsal and back pain. Two months prior, he had noticed progressive difficulty walking and numbness in his legs. Neurological examination revealed back tenderness and crural paraparesis. His reflexes were exaggerated and Babinski sign was present on both sides. Urine and stool incontinence were absent.

A magnetic resonance imaging (MRI) of the thoracolumbar spine showed an epidural lesion at the level of T7-8 that extended into the right neuroforamina, as well as intense postgadolinium enhancement (-Figs. 1 and 2). Signal flow voids could be seen on T2, indicating that the lesion was probably highly vascular (-Fig. 2). There was significant cord compression; however, the cord signal was normal.

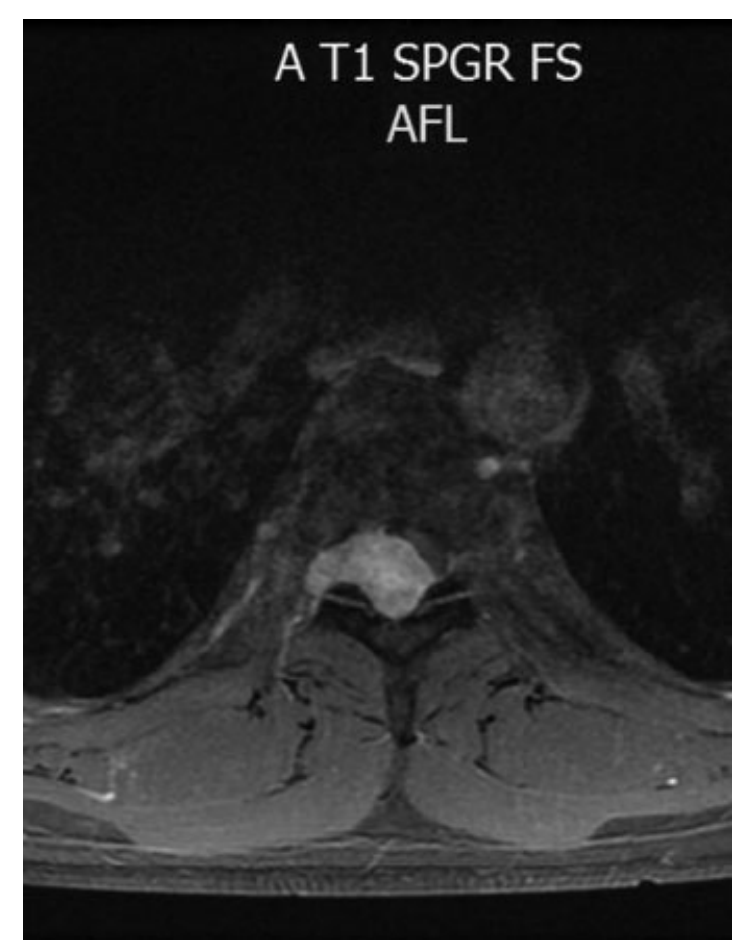

Fig. 1 Magnetic resonance images. Axial view. An epidural mass with foraminal extension is depicted compressing the spinal cord. Significant gadolinium enhancement can be seen. 


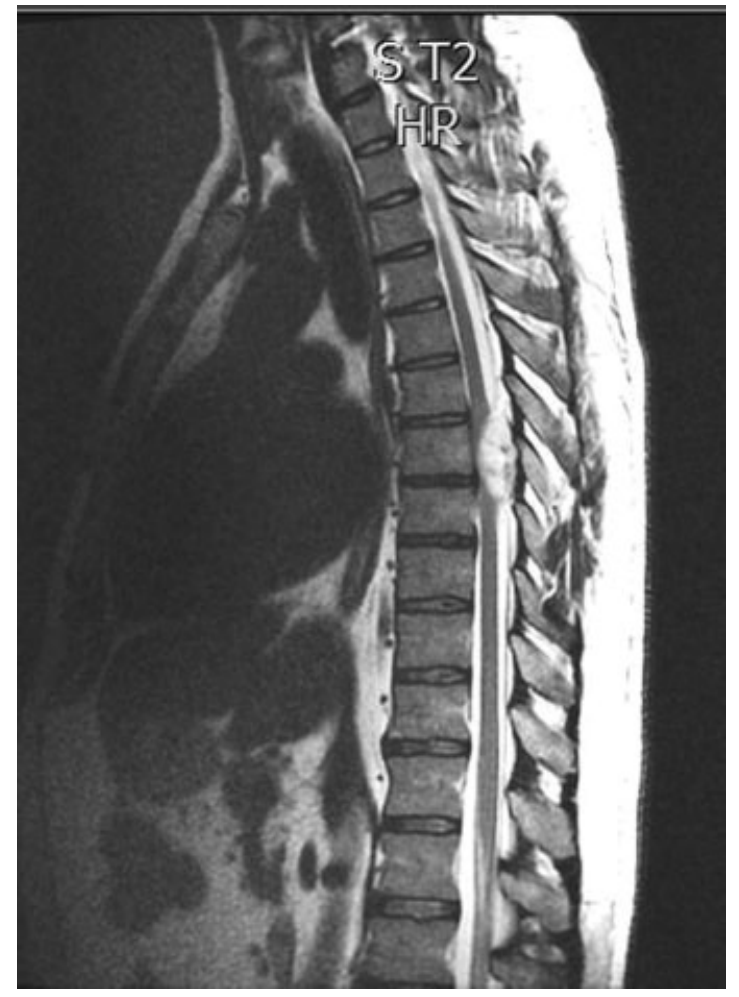

Fig. 2 Magnetic resonance images. Sagital view. An epidural lesion at the level of T7-8 presented intense postgadolinium enhancement. Signal flow voids may be noticed, indicating that the lesion was probably highly vascular.

He underwent a T6-8 laminectomy, bilaterally. Radioscopy was used to identify the level to be approached. Electrophysiological monitoring was employed to minimize the risks of neurological worsening. After laminectomy, a reddish epidural mass that extended into the right T7-8 foramina was revealed. We noticed two feeding vessels in its superolateral aspect, which we dissected and coagulated. They were soft upon manipulation and we completely resected after circumferential dissection. Then, we removed

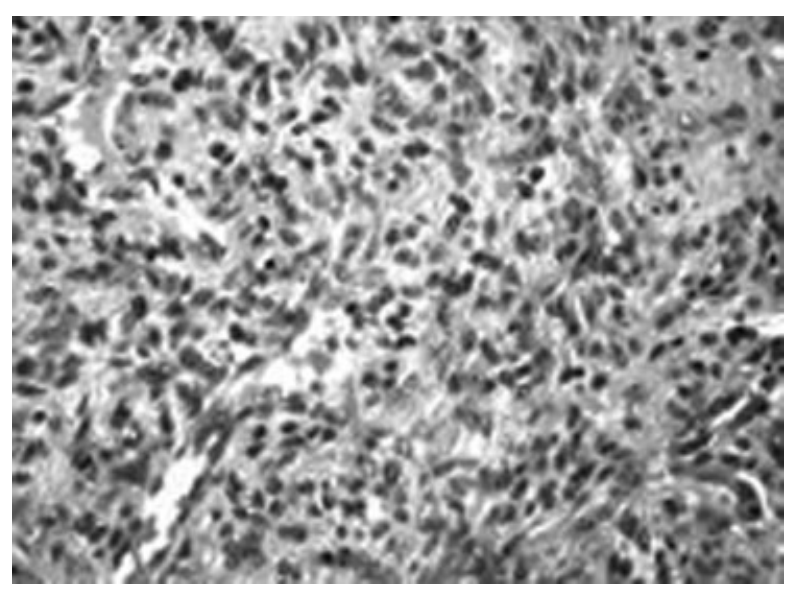

Fig. 3 Hematoxylin and eosin stain (x 32) shows a vascular tumor composed of vessels with various calibers. The walls of the vessels are lined with endothelium; there are no smooth muscles lining them. the foraminal extension. The postoperative period was uneventful and the patient was discharged with no additional neurological deficits.

Histopathological examination revealed a vascular tumor composed of vessels of several calibers. Endothelium lined the walls. We did not observe smooth muscles and saw fibrous septa between the vessels. This image diagnosed a capillary hemangioma (-Fig. $\mathbf{3}$ ).

\section{Discussion}

Hemangiomas are congenital vascular malformations pathologically considered as hamartomas and classified as capillary, cavernous, arteriovenous or venous, and usually located at soft tissue or bone, mainly in the spinal column. ${ }^{2,3,7-9}$ Vertebral hemangiomas are common, however purely epidural hemangiomas constitute rare findings. ${ }^{10,11}$ Although cases of purely epidural cavernous hemangiomas have been described, thus far, only three patients with epidural capillary hemangiomas have been reported. ${ }^{2,4,5}$

Differential diagnosis of epidural lesions includes nerve sheath tumors, meningiomas, hemangiopericytomas, hemangioblastomas, cavernous hemangiomas, and lymphomas. ${ }^{7,11-13}$ A constant feature of the previously reported cases is intervertebral foraminal extension, which is uncommon for a non-nerve sheath tumor. ${ }^{14,15}$ Therefore, schwannomas and capillary hemangiomas constitute the most frequent differential diagnosis. There are reports of spinal capillary hemangiomas in other locations, mainly the intradural and intramedullary spaces. ${ }^{7-9}$

The natural history of hemangiomas is poorly understood due to the scarcity of cases. ${ }^{7}$ All four cases presented with progressive myelopathy and pain. ${ }^{2,4}$ Myelopathy is thought to be related to the direct compression of the spinal cord or vascular steal phenomena. The cases of epidural capillary hemangioma did not present any signs of hemorrhage.

In all cases, the lesion was located at the thoracic spine. Radiological features were identical in every case reported thus far. MRI findings include an isointense lesion in T1-weighted images, with high signal in T2 and significant enhancement after gadolinium injection. We observed low density rim in two cases. ${ }^{2,4,5}$ Foraminal extension was radiologically appreciated in all cases, as well it was during surgical procedure. Such foraminal extension may be responsible for partial resection, even though no recurrence has been described thus far. ${ }^{2,4,5}$

Surgical resection should always be indicated, regardless of the clinical presentation, due to the risk of spinal cord compression. ${ }^{5,15}$ Laminectomy or laminotomy are the most used approaches. At surgery, the lesion presents as a reddish epidural mass with arterial feeders surrounding it. The surgeon must identify and divide the feeding vessels. It is important to carefully dissect the lesion itself circumferentially away from the dura and exercise judicious hemostasis. Total surgical resection is feasible, although intervertebral foraminal extension may preclude it.

Most epidural hemangiomas are cavernous, constituting an important histological differential diagnosis. ${ }^{1,3,6}$ 
Cavernous hemangiomas are comprised of a large number of sinusoidal channels in collagenous tissue, ${ }^{6}$ whereas the capillary hemangioma are composed of thin irregular capillary-sized vessels in a fibrotic stroma, determining a lobular architecture. ${ }^{3,14}$ Basal lamina is continuous and of low mitotic activity presenting no atypia. Capillary hemangiomas stain positively for CD 31 and CD 34; 1,3,6,15 however, their reaction for S100 and epithelial membrane antigen is negative. ${ }^{1}$

\section{Conclusion}

Pure epidural capillary hemangiomas are extremely rare lesions that should be included in the differential diagnosis of spinal epidural lesions. They differ from more common lesions, mainly schwannomas, primarily due to their foraminal extension, which also may differentiate them from cavernous hemangiomas. Surgical excision is mandatory and intervertebral foraminal extension may preclude gross total resection.

\section{Conflicts of Interest}

The authors received no funds in support of this work. No benefits in any form have been or will be received from a commercial entity with financial interests related directly or indirectly to the subject of this manuscript.

\section{References}

1 Aoyagi N, Kojima K, Kasai H. Review of spinal epidural cavernous hemangioma. Neurol Med Chir (Tokyo) 2003;43(10):471-475, discussion 476

2 Badinand B, Morel C, Kopp N, Tran Min VA, Cotton F. Dumbbellshaped epidural capillary hemangioma. AJNR Am J Neuroradiol 2003;24(2):190-192
3 Caruso G, Galarza M, Borghesi I, Pozzati E, Vitale M. Acute presentation of spinal epidural cavernous angiomas: case report. Neurosurgery 2007;60(3):E575-E576, discussion E576

4 Gupta S, Kumar S, Banerji D, Pandey R, Gujral R. Magnetic resonance imaging features of an epidural spinal haemangioma. Australas Radiol 1996;40(3):342-344

5 Hasan A, Guiot MC, Torres C, Marcoux J. A case of a spinal epidural capillary hemangioma: case report. Neurosurgery 2011;68(3): E850-E853

6 Jo BJ, Lee SH, Chung SE, et al. Pure epidural cavernous hemangioma of the cervical spine that presented with an acute sensory deficit caused by hemorrhage. Yonsei Med J 2006; 47(6):877-880

7 Alakandy LM, Hercules S, Balamurali G, Reid H, Herwadkar A, Holland JP. Thoracic intradural extramedullary capillary haemangioma. Br J Neurosurg 2006;20(4):235-238

8 Bozkus H, Tanriverdi T, Kizilkiliç O, Türeci E, Oz B, Hanci M. Capillary hemangiomas of the spinal cord: report of two cases. Minim Invasive Neurosurg 2003;46(1):41-46

9 Hida K, Tada M, Iwasaki Y, Abe H. Intramedullary disseminated capillary hemangioma with localized spinal cord swelling: case report. Neurosurgery 1993;33(6):1099-1101

10 Roncaroli F, Scheithauer BW, Krauss WE. Hemangioma of spinal nerve root. J Neurosurg 1999;91(2, Suppl)175-180

11 Shin JH, Lee HK, Jeon SR, Park SH. Spinal intradural capillary hemangioma: MR findings. AJNR Am J Neuroradiol 2000;21(5): 954-956

12 Zander DR, Lander P, Just N, Albrecht S, Mohr G. Magnetic resonance imaging features of a nerve root capillary hemangioma of the spinal cord: case report. Can Assoc Radiol J 1998;49(6): $398-400$

13 Kang JS, Lillehei KO, Kleinschmidt-Demasters BK. Proximal nerve root capillary hemangioma presenting as a lung mass with bandlike chest pain: case report and review of literature. Surg Neurol 2006;65(6):584-589, discussion 589

14 Karikari IO, Selznick LA, Cummings TJ, George TM. Spinal capillary hemangioma in infants: report of two cases and review of the literature. Pediatr Neurosurg 2007;43(2):125-129

15 Nowak DA, Widenka DC. Spinal intradural capillary haemangioma: a review. Eur Spine J 2001;10(6):464-472 